\title{
Predatory interaction between the brachyuran crab Cancer pagurus and decapod crustacean prey
}

\author{
P. Lawton* \\ School of Animal Biology, University College of North Wales, Bangor, Gwynedd, Wales LL57 2UW, United Kingdom
}

\begin{abstract}
In laboratory experiments Cancer pagurus successfully subdued a wide size range of decapod crustaceans (conspecifics, Galathea squamifera, Pilumnus hirtellus, Pisidia longicornis, and Porcellana platycheles). Mishandling by C. pagurus, prey retaliation, and prey limb autotomy contributed to attack failure. A simple grab response dominated the pursuit phase of predatory interaction, although $C$. pagurus also pounced on, and actively stalked, decapod crustaceans. Handling times, $T_{h}$, were long (up to $1.44 \mathrm{~h}$ ), due to an extended consumption phase. By comparison, involvement time, $\mathrm{T}_{\mathrm{i}}$, in unsuccessful predation attempts was much shorter (median $\mathrm{T}_{i}<180 \mathrm{~s}$ for all prey species). Profitability (prey energy content $(\mathrm{kJ}) / T_{\mathrm{h}}$ ) increased linearly with prey size for one size class of $C$. pagurus feeding on $P$. platycheles. Due to incomplete consumption, energy intake (kJ predator ${ }^{-1} \mathrm{~d}^{-1}$ ) from an unrestricted diet of $P$. platycheles was considerably lower than numerical predation and whole prey energy content would suggest. Nevertheless, decapod crustaceans proved to be energetically valuable, if somewhat elusive, prey for $C$. pagurus. Predation success rate of $C$. pagurus on $P$. platycheles was $<0.5$ in open encounters. However, when provided with shelter, $C$. pagurus adopted ambush predation techniques to capture $P$. platycheles, thereby compensating for the relatively low predation success observed in open encounters with this decapod crustacean prey.
\end{abstract}

\section{INTRODUCTION}

Crustacean prey occur in decapod crustacean stomach contents (Hill 1976, Williams 1982, Elner \& Campbell 1987), including those of brachyuran crabs in the genus Cancer (Butler 1954, Gotshall 1977, Shelton et al. 1979, Stevens et al. 1982, Elner et al. 1985). Surprisingly, there are few quantitative behavioral studies of this predation (Evans \& Mann 1977, Hirtle \& Mann 1978, Paul 1981, Morales \& Antezana 1983, ap Rheinallt \& Hughes 1985, ap Rheinallt 1986), in contrast to the extensive literature on molluscan predation by decapods (Lau 1987).

Wamer (1977) considered that fast-moving prey, such as crustaceans, could generally only be captured by portunids and rapidly-moving semi-terrestrial or terrestrial crabs. However, a 'sit-and-wait' or 'ambush' predation strategy has been posited for some relatively slow-moving crabs (Hughes 1966, Hill 1979, Schembri 1981, Morales \& Antezana 1983).

\footnotetext{
- Present address: Department of Fisheries and Oceans, Biological Station, St Andrews, New Brunswick, Canada EOG $2 \times 0$
}

European edible crabs Cancer pagurus occupy sublittoral-fringe, and shallow sublittoral habitats on northeastern Atlantic rocky coasts (Ingle 1980). Conspicuous among the mobile epifauna of these habitats on North Wales shores, sympatric with C. pagurus, are several other decapod crustaceans (Lawton 1983), Carcinus maenas (Portunidae), Galathea squamifera (Galatheidae), Pilumnus hirtellus (Xanthidae), Pisidia longicornis, and Porcellana platycheles (Porcellanidae).

In view of the paucity of data on predatory interaction between crustaceans, the following topics were examined in this study. (1) Predation techniques used by recently captured Cancer pagurus. (2) Feeding performance in terms of predation success rate (sensu Holling 1966). (3) Handling times and prey profitability (defined as the ratio of prey energy content to handling time; Elner \& Hughes 1978). (4) Foraging tactics used by C. pagurus to exploit decapod crustacean prey.

Cancer pagurus was observed feeding on all 5 decapod crustaceans, and on conspecifics. Porcellana platycheles formed the principal prey species, being numerically abundant at the collection sites, and easily maintained in the laboratory. 


\section{METHODS}

Predators, Cancer pagurus (males only), and prey species (both sexes; Fig. 1), were collected between August 1980 and June 1981 from sublittoral-fringe habitats on 2 North Wales rocky shores; Treborth (Ordnance Survey reference SH552713), and Church Island (SH552716). Predators were placed singly in 0.4 $\times 0.2 \mathrm{~m}$ aquaria supplied with recirculating seawater (ambient temperature; salinity ca 33\%). Prey were held in single species groups in similar aquaria. Photoperiod followed natural sunrise and sunset, ranging from 16:8 to 8:16 (h light:h dark). Prey presentations commenced after $12: 00 \mathrm{~h}$ on any given day, and frequently continued into the dark phase of the photoperiod (under low-level illumination in the near infrared).
A

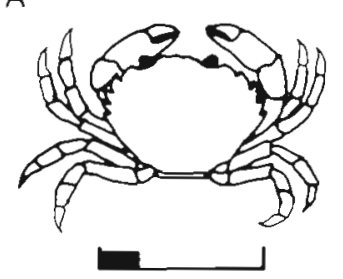

C

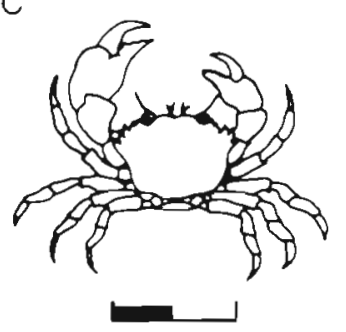

E

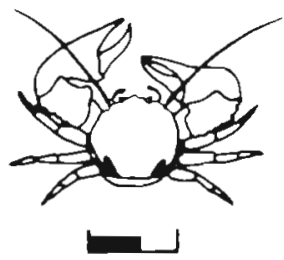

B

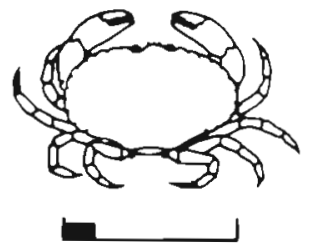

D

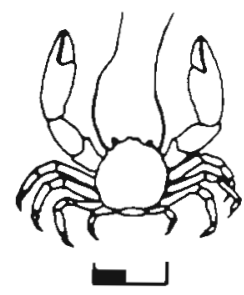

$\mathrm{F}$

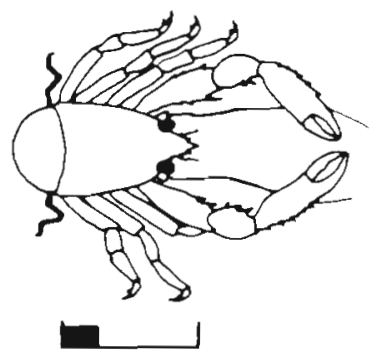

Fig. 1. Decapod crustacean prey species. Line bars indicate measured body dimension, carapace width (CW) for Carcinus maenas (A), Cancer pagurus (B), Pilumnus hirtellus (C), Pisidia longicornis (D), and porcellana platycheles (E). Carapace length, $\mathrm{CL}$, of Galathea squamifera (F) was measured from the tip of the medial spine on the rostrum to the dorsal margin of the carapace along the anterior-posterior axis. Solid bar under each illustration indicates the height of the master claw relative to the prey body dimension
Predation techniques. (1) Porcellana platycheles prey: Ten recently captured predators $(61$ to $120 \mathrm{~mm}$ carapace width, CW; held for $<5 \mathrm{~d}$ ) were presented individually with $5 \mathrm{P}$. platycheles $\{6.4$ to $13.9 \mathrm{~mm} \mathrm{CW}$; 1 prey $\mathrm{d}^{-1}$ ). Each trial was observed for at least $15 \mathrm{~min}$; if no attack occurred within 7 min, a 'passive' encounter was staged by gently coaxing the prey towards the predator. When an attack ensued, observations were extended until the feeding bout ended. Otherwise, predatory activity was assessed the following morning.

(2) Other decapod prey: Nine recently captured predators (70 to $91 \mathrm{~mm} \mathrm{CW}$ ) were presented with Pisidia longicornis ( 5.1 to $8.1 \mathrm{~mm} \mathrm{CW}$ ) as prey, following procedures outlined for $P$. platycheles.

Feeding performance. Feeding performance was analyzed in terms of predation success rate (Holling 1966; see also Evans \& Mann 1977):

Predation success $=$ recognition success $\times$ pursuit success $\times$ attack success

Where recognition success $=$ no. of encounters leading to pursuit/no. of encounters; pursuit success $=$ no. of captures/no. of pursuits; attack success $=$ no. of prey or chelipeds consumed/no. of captures. Prey were encountered through direct physical contact and by olfaction, the latter being recognizable by synchronous orientation of the predators antennules towards the prey, and an increase in antennular flicking rate (Pearson et al. 1979, Lawton \& Hughes 1985).

(1) Porcellana platycheles prey: Six predators $(75$ to $85 \mathrm{~mm}$ (W) were presented with 4 size classes of prey ( $<7.9 ; 8.0$ to $9.9 ; 10.0$ to $11.9 ; 12.0$ to $13.9 \mathrm{~mm} \mathrm{CW}$ ), continuing until 30 observations (per size class) were obtained on pursuit and attack success. Prey (a maximum of 4 daily) were gently lowered into the aquarium 30 to $50 \mathrm{~mm}$ from the predator ${ }_{\text {; }}$ if no pursuit occurred, a passive encounter was staged. Trials in which prey were not pursued after an encounter provided information on recognition success.

(2) Other decapod prey: Individual predators (69 to $120 \mathrm{~mm} \mathrm{CW}$ ) were presented with 5 prey (1 prey $\mathrm{d}^{-1}$ ) from one of the following species: Cancer pagurus, Carcinus maenas, Pilumnus hirtellus, or Galathea squamifera. Prey were presented to 3 predators from each of 2 groups which differed in recent feeding history. The first group $(n=12)$ comprised recently captured predators $(<2$ wk in captivity) which had fed on decapods in the laboratory (DEC group). The second group ( $n=12$ ) consisted of predators, held for $>2 \mathrm{wk}$, which had fed on molluscan prey only during captivity (MOLL group). Prey size was expressed as prey body dimension (Fig. 1)/predator CW, PROP, in this experiment which used 4 prey species, and a wide size range of predators. Predators which did not feed on a particu- 
lar prey species were subsequently given 2 Porcellana platycheles to assess their response to alternate decapod prey.

Handling times and prey profitability. (1) Porcellana platycheles prey: Handling time $\left(T_{h}, s\right)$ and tissue consumption (estimated visually) were recorded for 3 predators ( 80 to $82 \mathrm{~mm} \mathrm{CW}$ ). Handling times were related to prey size using prey $\mathrm{CW}(\mathrm{mm}) /$ predator chela height $(\mathrm{mm})$ as a measure of relative prey size, RPS. Energy content $(\mathrm{E}, \mathrm{kJ})$ of $P$. platycheles, with adjustment for incomplete prey consumption, was obtained following procedures given in the Appendix. Profitability was expressed as $\mathrm{E} / \mathrm{T}_{h}$, following Elner \& Hughes (1978).

(2) Other decapod prey: Handling times, and involvement times $\left(\mathrm{T}_{1}, \mathrm{~s}\right)$ when predation attempts failed were recorded during the presentations described under 'Feeding performance'. Profitability relationships were not determined for other decapod prey.

Foraging tactics. For each of 4 trials, 4 to 5 Cancer pagurus $(75$ to $85 \mathrm{~mm} \mathrm{CW}$ ) were collected by SCUBA divers from sublittoral sites in the Menai Straits, North Wales (SH540709). Porcellana platycheles $(n=12)$ were given to these crabs on the day following capture. On the 3rd day in captivity, 1 predator was selected and placed into a $0.77 \times 0.48 \mathrm{~m}$ observation tank. Within an oval arena of $0.2 \mathrm{~m}^{2}$ basal area inside this tank, an opening along one side led to a shelter (inside dimensions: $135 \times 70 \times 90 \mathrm{~mm} ; \mathrm{W} \times \mathrm{H} \times \mathrm{D})$. On Day 4 , $10 P$. platycheles from each of 2 size classes $(<10 \mathrm{~mm}$; $>11 \mathrm{~mm} \mathrm{CW}$ ) were placed into the arena $1 \mathrm{~h}$ after the onset of the dark phase. Prey were replaced twice-daily over the next $4 \mathrm{~d}$ to maintain prey availability. At these times, prey remains were removed, and surviving prey assessed for predator-induced injury.

Predator and prey behavior was monitored each night for 2 trials (with Predators A and B). Videorecording commenced $1 \mathrm{~h}$ into the dark phase of the photoperiod (facilitated by low-level illumination in the near infra-red), continuing for $12 \mathrm{~h}$ thereafter. In the trials with Predators C and D, prey remains were collected daily to estimate energy intake $\left(\mathrm{kJ}\right.$ predator ${ }^{-1}$ $\mathrm{d}^{-1}$ ) on an unrestricted diet of Porcellana platycheles.

\section{RESULTS}

\section{Predation techniques}

(1) Porcellana platycheles prey: Prey were recognized at distances of 30 to $50 \mathrm{~mm}$ through olfaction; however, most direct encounters were passive $165.6 \%$; $n=32$ ), following prey movement towards the predator. Three pursuit techniques were recognized. In the grab response, the prey was swept under the predators' abdomen using one or more pereopods (median pursuit time $=30 \mathrm{~s} ; n=18$ ). In the pounce response, the predator executed a rapid forward movement (from a resting position) towards the prey, which it then captured by bringing the pereopods together under the abdomen (median pursuit time $=5 s ; n=13$ ). Stalking (one $47 \mathrm{~s}$ sequence) occurred when the predator rose from a resting position, fully extended all pereopods, and moved off slowly in pursuit of the prey. A rapid downward movement, similar to that used in the pounce response, secured the prey item.

Following capture, small prey were moved directly to the mouthparts. Attacks on larger prey were initially directed at the chelipeds, leading to autotomy in 14 attacks. Retaliation, in which a prey cheliped closed forcibly over a predator body-part, occurred in 5 attacks on large Porcellana platycheles, from which 4 prey escaped. Prey also escaped due to mishandling by the predator. Median subjugation time (elapsed time from taking the prey up in the claws, until immobilization) was $60 \mathrm{~s}(n=18)$.

Consumption was the longest phase of predatory interaction (Table 1). Small prey were ingested entirely, whereas the dorsal carapace of large prey was first broken open, thus allowing the predator access to body tissues. Predators frequently removed pereopods from large prey, breaking them open to feed upon the exposed muscle tissue. Following autotomy, or as part of a feeding bout, predators also fed on one or both prey chelipeds.

(2) Other decapod prey: Predation techniques used on Pisidia longicornis were very similar to those used on Porcellana platycheles, differences being attributable to the specific morphology of each species (Fig. 1). Median pursuit time was $23 \mathrm{~s}(n=18)$ and $7 \mathrm{~s}(n=3)$, respectively, for the grab and pounce responses; no stalking behavior was observed. Median subjugation time for $P$. longicornis prey was $172 \mathrm{~s}(n=17)$, while the median duration of the consumption phase approximated $10 \mathrm{~min}$ (Table 1).

\section{Feeding performance}

(1) Porcellana platycheles prey: Recognition success was higher, and less variable, for active prey encounters $(0.80 \pm 0.10$, mean \pm standard deviation; 67 encounters with 6 predators), than for passive ones $(0.67 \pm 0.21 ; 163$ encounters). Pursuit success averaged 0.78 (over all methods and prey sizes). The grab response was used most frequently ( $67.5 \%$ of pursuits), but was less successful on large prey than the pounce response (28.3\% of pursuits). Stalking behavior was observed in 5 presentations. 
Table 1 Cancer pagurus and 2 decapod crustacean prey. Med. dur.: Median duration (s) of the consumption phase of predatory interaction

\begin{tabular}{|lccc|}
\hline Degree of consumption & \multicolumn{2}{c}{ Porcellana platycheles } & \multicolumn{2}{c|}{ Pisidia longicornis } \\
& Med. dur. & $n$ & Med. dur \\
Small prey, consumed entirely & 196 & 3 & 671 \\
Large prey, consumed in part: & 199 & 12 & 12 \\
One cheliped & 305 & 5 & \\
Two chelipeds & 245 & 6 & 559 \\
Body tissues & 608 & 10 & 12 \\
Body tissues, chelipeds, and pereopods & & 5 \\
\hline
\end{tabular}

Full attack success (in which the whole prey was subdued) was maximal at intermediate prey size (Fig. 2A). The main cause of failure with large prey was cheliped autotomy (Fig. 2B), while mishandling led to
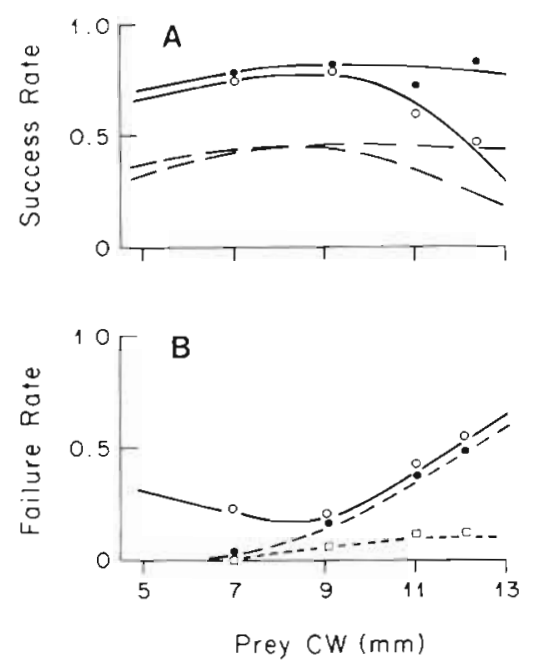

Fig. 2. Cancer pagurus and Porcellana platycheles prey. (A) Predation success. Solid lines indicate relation between attack success and prey size $(\mathrm{CW}, \mathrm{mm})$ : $\Leftrightarrow$ full attack success (predator subdued the whole prey); $(\bullet$ total attack success (full + partial success, in which predator obtained prey cheliped only). Dashed lines indicate predation success, with and without adjustment for partial attack success. (B) Cause of failure in unsuccessful attacks. Lines indicate cumulative proportion of attacks which failed due to one of the following causes: ( $=$ ) retaliation by prey; $(\bullet$ autotomy of one or both prey chelipeds; () mishandling by predator

most failures with small prey Retaliation occurred in only a small proportion of attacks (Fig. 2B). When the consumption of autotomized chelipeds was taken into account (partial attack success), total attack success (full + partial success) remained high for large prey (Fig. 2A). Using average values for recognition and pursuit success, data on attack success were adjusted to derive predation success rate, this being $<0.5$ for all prey sizes (Fig. 2A)

(2) Other decapod prey: Predators which had recently fed on decapod prey (DEC group) were cap- able of subduing small conspecifics (Table 2; PROP range 0.16 to 0.29 ); however, none of the 5 prey attacked were consumed. A distinct rejection behavior was observed when conspecifics were crushed or moved to the mouthparts for inspection. The behavior involved antero-lateral extension of the cheliped holding the prey, with release at a distance from the predator (median rejection time $=89 s ; n=5$ ). At the end of the trial, by which time the predators had not eaten for $7 \mathrm{~d}, 2$ Porcellana platycheles were consumed within 3 h.

Only 1 predator in the group maintained on molluscan prey (MOLL group) exhibited similar behavior (median rejection time $=109 \mathrm{~s}, n=3$ ). The other 2 MOLL group predators consumed all conspecific prey offered to them (PROP range 0.2 to 0.44 ). These predators actively searched for small conspecifics, attacking most of those encountered (Table 2), whereas none of the DEC group predators attempted to locate conspecifics. Pursuit and attack success rates were high, reflecting an inadequate defensive capability (Table 2 ). On capture, small C. pagurus did not readily autotomise limbs, while retaliation was ineffective due to a relatively small chela size (Fig. 1).

Predation on small Carcinus maenas by DEC group predators was low, with only 4 prey consumed (Table 2). Observed predation success was similarly low for the MOLL group, although these predators consumed 13 C. maenas overnight. Predators in both groups responded to the introduction of $C$. maenas by active searching behavior, but pursuit success on this species was low, particularly for larger predators. However, attack success on captured C. maenas prey was high (Table 2), again reflecting an ineffective defensive capability (Fig. 1).

Both predator groups preyed successfully on Pilumnus hirtellus (Table 2). Predators from the DEC group responded primarily to direct contacts, while predators in the MOLL group actively searched for $P$. hirtellus. All predators consumed the largest prey offered (maximum PROP $=0.33$ ), although handling difficulties became evident. $P$. hirtellus reacted to predation attempts with autotomy and direct retaliation, the latter 
Table 2. Cancer pagurus and 4 decapod crustacean prey. Predation success rate (PSR) derived as the product of recognition success (no. of encounters leading to pursuit/no. of encounters), pursuit success (no. of captures/no. of pursuits), and attack success (no. of prey or chelipeds consumed/no. of captures) for each of 2 predator groups: (A) Predators with recent $(<2$ wk) exposure to decapod crustacean prey (DEC group); (B) Predators held in the laboratory $>2$ wk, and which had fed on molluscan prey only (MOLL group). Five prey were presented to 3 predators in each species/predator grouping yielding 15 encounters, the denominator in recognition success

\begin{tabular}{|c|c|c|c|c|c|c|c|c|}
\hline \multirow{2}{*}{$\begin{array}{l}\text { Prey species: } \\
\text { Predator group: }\end{array}$} & \multicolumn{2}{|c|}{ Cancer pagurus } & \multicolumn{2}{|c|}{ Carcinus maenas } & \multicolumn{2}{|c|}{ Pilumnus hirtellus } & \multicolumn{2}{|c|}{ Galathea squamifera } \\
\hline & $\mathrm{DEC}$ & MOLL & $\mathrm{DEC}$ & MOLL. & $\mathrm{DEC}$ & MOLL & $\mathrm{DEC}$ & MOLL \\
\hline Recognition & 0.33 & 0.93 & 0.75 & 0.53 & 0.93 & 1.00 & 0.87 & 0.93 \\
\hline Pursuit & 1.00 & 0.79 & 0.55 & 0.36 & 0.64 & 0.88 & 0.28 & 0.43 \\
\hline Attack & 1.00 & 1.00 & 0.60 & 1.00 & 0.78 & 0.73 & 1.00 & 1.00 \\
\hline PSR & 0.33 & 0.73 & 0.25 & 0.19 & 0.46 & 0.64 & 0.24 & 0.40 \\
\hline
\end{tabular}

defense being particularly effective, terminating the predation attempt in 4 cases.

Both DEC and MOLL group predators responded to the swimming movements of Galathea squamifera by attempting to capture these prey; however, pursuit success was low (Table 2). Due to limited size availability, some captured $G$. squamifera could not easily be consumed. Notwithstanding this size discrepancy, 22 of the 30 galatheids presented were consumed overnight. Following capture, G. squamifera were restrained by the pereopods while the predator attempted to immobilize the long, slender chelipeds (Fig. 1), these appendages being autotomized in most attacks, leading to escape on 3 occasions.

\section{Handling times and prey profitability}

(1) Porcellana platycheles prey: For predators consuming small prey entirely, or feeding on the body only (or body and pereopods) of larger prey (RPS >0.4), handling time was linearly related to relative prey size, RPS (Fig. 3A). Handling time was also linearly related to RPS when predators fed only upon autotomized chelipeds (Fig. 3A), the slope for this latter relation being significantly higher than the former $(t=1.967$; d.f. $=50$ (1); $p<0.05$ ).

Using an energy conversion factor (Appendix), and appropriate ash-free dry weight regression (Appendix; Table $3 \mathrm{~A}$ ), the energy content of prey body-parts available in each handling episode was estimated, and adjusted for incomplete ingestion (Table 3B). Realized profitability $\left(E / T_{h}\right)$ increased linearly with RPS when predators consumed small prey entirely, or fed on the body only (or body and pereopods) of prey $>0.4$ RPS (Fig. 3B). Profitability of large prey chelipeds alone was lower than that gained from feeding upon the body tissues of prey of equivalent RPS (Fig. 3B). Evidently, there was no energetic basis for predators concentrating on the autotomized chelipeds of large prey.

(2) Other decapod prey: Handling times ranged up to
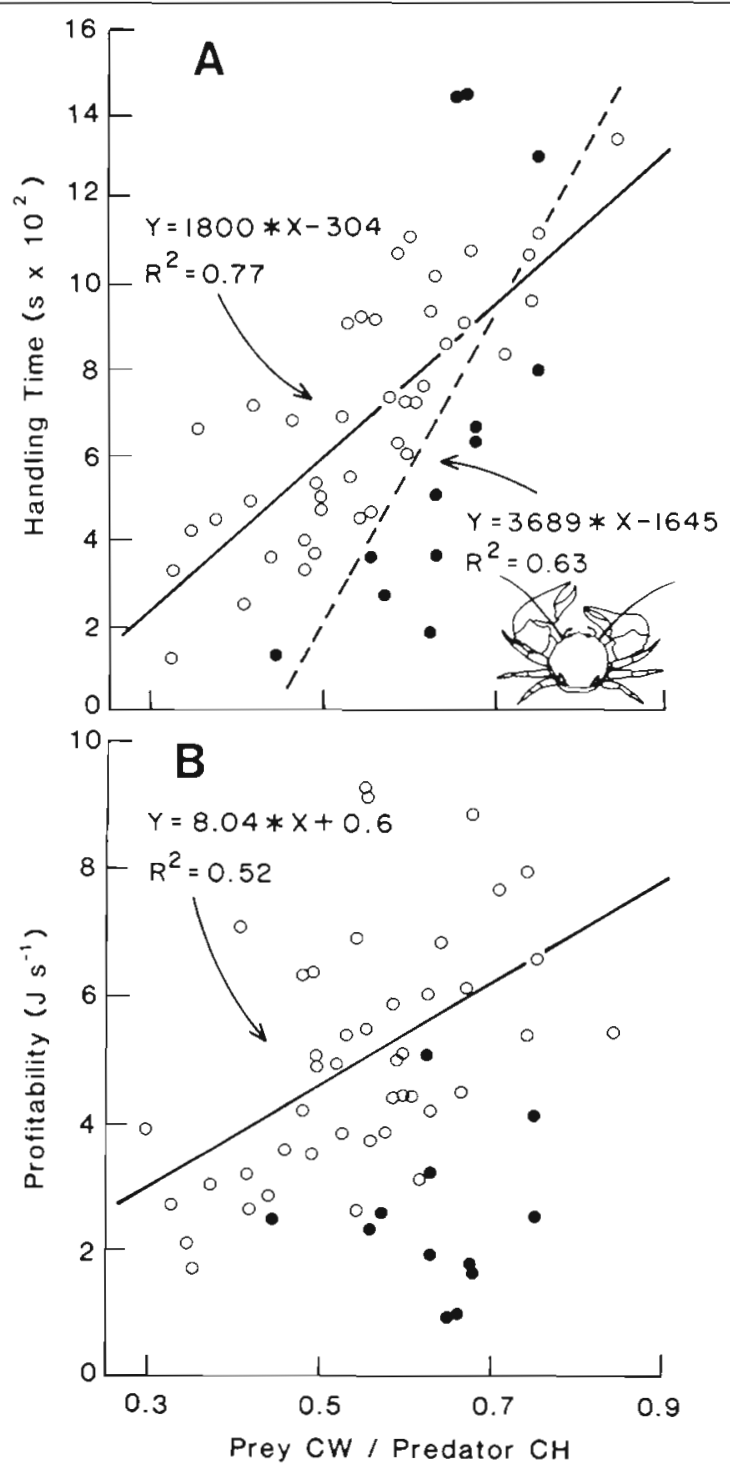

Fig. 3. Cancer pagurus and Porcellana platycheles prey. (A) Handling time, $T_{h}$. (O) $T_{h}$ when feeding on whole prey; $(\bullet) T_{h}$ when feeding on autotomized chelipeds. Equations are in the form $Y=B X+A$, where $Y=\mathrm{T}_{\mathrm{h}}$ (s) and $X=$ prey $\mathrm{CW}(\mathrm{mm}) /$ predator chela height $(\mathrm{mm})$, RPS. (B) Profitability. Symbols as for (A). Equation is for profitability of whole prey, where $Y=$ profitability $\left(\mathrm{J} \mathrm{s}^{-1}\right)$, and $\mathrm{X}=\mathrm{RPS}$ as in $(\mathrm{A})$ 
Table 3. Cancer pagurus and Porcellana platycheles prey. Regression equations used in estimation of prey profitability. (A) Ash-free carbonate corrected dry weight, AFCC, of prey body-parts related to prey size, $C W$ : equations in the form $\log _{e}$ $Y=\log _{e} A+B \log _{e} X$, where $Y=A F C C(g)$ of body-part (body and pereopods, bp; cheliped, $\mathrm{ch}_{\text {; }}$ whole prey, w), and $X=\mathrm{CW}$ $(\mathrm{mm})$. (B) Proportion of prey left as remains, $P_{r}$, related to relative prey size, RPS: equations in the form $Y=A+B X$, where $Y=$ mean $\mathrm{P}_{\mathrm{r}}$ (AFCC of remains, $g / A F C C$ available for consumption, $g_{i} n=4$ ), and $X=R P S$ (prey $C W, \mathrm{~mm} /$ predator chela height, mm)

\begin{tabular}{|crccc|}
\hline \multicolumn{1}{c}{$Y$} & \multicolumn{1}{c}{$A$} & $B$ & $n$ & $r^{2}$ \\
\hline (A) & & & & \\
AFCC $_{\text {bp }}$ & -8.679 & 2.789 & 28 & 0.96 \\
AFCC $_{\mathrm{ch}}$ & -10.318 & 3.415 & 28 & 0.97 \\
AFCC $_{\mathrm{w}}$ & -8.714 & 3.069 & 28 & 0.95 \\
(B) & & & & \\
$\mathrm{P}_{\mathrm{r}}$ (whole prey) & -0.207 & 0.574 & 5 & 0.98 \\
$\mathrm{P}_{\mathrm{r}}$ (cheliped) & 0.126 & 0.371 & 5 & 0.88 \\
\hline
\end{tabular}

$1.44 \mathrm{~h}$ for other decapod prey, with considerable overlap between proportional prey size categories (Table 4). As was the case with Porcellana platycheles, these extreme handling times were due principally to an extended consumption phase. By comparison, involvement time in unsuccessful predation attempts was much shorter. Median $T_{1}$, regardless of the cause of attack failure (autotomy, retaliation, mishandling, or rejection of conspecific prey), was $<180 \mathrm{~s}$ for each species.

\section{Foraging tactics}

Both of the video-monitored predators occupied shelter during inactive periods (Predator A for ca $8 \mathrm{~h}$ each night). Out of shelter activity for Predator A was most pronounced from the time of high tide to that of the subsequent low tide (Fig, 4). During activity periods outside shelter Predator A showed limited response to prey encounters (2 pursuits out of 119 encounters during night 1; 0.02 as a proportion). Conversely, a higher proportion of prey encounters at the shelter elicited pursuit ( 8 out of 15 encounters during night $1 ; 0.53$ ). Differential response was also evident in the amount of time engaged in feeding activity outside shelter for Predator A (38 min over 4 nights) compared to time engaged in feeding within shelter (Fig. 4). Predator B only left the shelter on 1 occasion (for $10 \mathrm{~min}$ on the second night), but was observed at the entrance, and to be active within shelter on other nights.

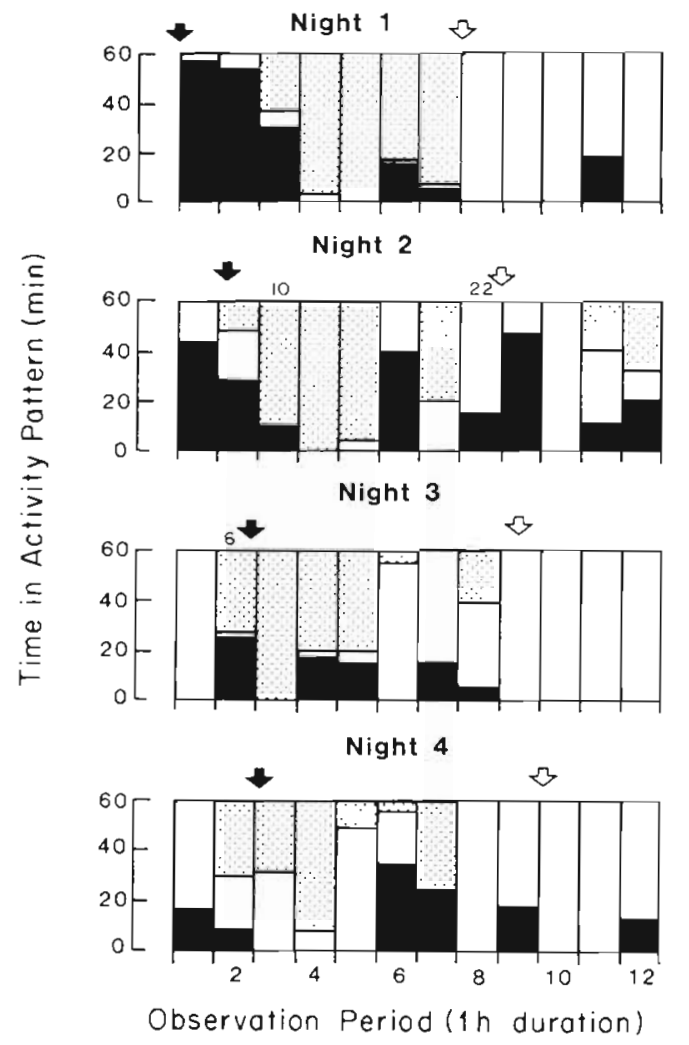

Fig. 4. Cancer pagurus and Porcellana platycheles prey. Activity pattern of Predator A, monitored for $12 \mathrm{~h}$ each night over $4 \mathrm{~d}$. Open portion of each bar: time in shelter (with no feeding observable) during each $1 \mathrm{~h}$ observation period; stippled portion: time spent in general activity outside shelter; solid portion: time engaged in foraging activity within or directly from shelter. Numbers above individual bars on Nights 2 and 3 indicate amount of time engaged in foraging activity outside shelter Solid arrow: time of high tide, open arrow: time of low tide, for each night

Table 4. Cancer pagurus and 4 decapod crustacean prey. Median handling times, $T_{h}$ (in $h$ ), with range and number of observations (in parentheses). Prey/predator size ratio, PROP $=$ prey $\mathrm{CL}$ or $\mathrm{CW}(\mathrm{mm}) /$ predator $\mathrm{CW}(\mathrm{mm})$

\begin{tabular}{ccccc}
\hline PROP & Cancer pagurus & Carcinus maenas & Pilumnus hirtellus & Galathea squamifera \\
\hline $0.1-0.19$ & & $0.11(1)$ & $0.93(5)$ & $0.54(3)$ \\
$0.2-0.29$ & $0.50(4)$ & $0.69(7)$ & $(0.30-1.27)$ & $(0.51-0.58)$ \\
$0.3-0.39$ & $(0.48-0.61)$ & $(0.23-0.99)$ & $0.86(12)$ & $0.56(4)$ \\
& $0.78(3)$ & & $0.30-1.44)$ & $(0.21-1.18)$ \\
$>0.4$ & $(0.44-1.34)$ & & & \\
& $1.12(1)$ & & & \\
\hline
\end{tabular}


Porcellana platycheles detected and avoided predators at distances of 30 to $50 \mathrm{~mm}$, increasing locomotory rate, and/or changing direction of movement. A total of 178 avoidance responses were noted during Night 1 of the trial with Predator A. Prey did not move extensively when the predators were in shelter, but aggregated (in groups of 2 to 5 ) along the arena sides. Prey activity increased following predator emergence from shelter.

Shelter-related foraging behavior, directly observed for predators $A$ and $B$, included attacking prey which moved across the shelter entrance, returning to the shelter with a prey item captured during general activity, and specific attack movements from within shelter. In the latter case, the predator exited from shelter, captured a prey and immediately returned.

Using numerical predation data, consumption was confirmed to be greatest within the shelter for all 4

Table 5. Cancer pagurus and Porcellana platycheles prey. Numerical predation over a $4 \mathrm{~d}$ period. Data are separated by the time (Night/Day) and location (Shelter/Arena) of prey consumption, inferred from the location of prey remains, collected twice-daily

\begin{tabular}{|crrrrr|}
\hline & \multicolumn{5}{c|}{$\begin{array}{c}\text { Time and location of prey consumption } \\
\text { Night }\end{array}$} \\
$\begin{array}{l}\text { Predator } \\
\text { identity }\end{array}$ & $\begin{array}{c}\text { Shelter } \\
\text { Darena }\end{array}$ & Shelter & Arena & Total \\
\hline A & 37 & 11 & 3 & 0 & 51 \\
B & 10 & 0 & 4 & 2 & 16 \\
C & 15 & 1 & 7 & 2 & 25 \\
D & 6 & 3 & 10 & 2 & 21 \\
\hline
\end{tabular}

predators ( $G$ test, all $p<0.05$; Table 5). As interactions were not significant ( $G$ test, $G_{(\mathrm{snt})}=2.8$; d.f. $=3 ; p>0.25$ ), these data were pooled ( $G$ test, $G=48.14$; d.f. $=1$; $p<0.001)$. Predation was heaviest overnight in the trial with Predator A ( $G$ test; $G=47.88$; d.f. $=1 ; p<0.001)$; however, there was no significant diurnal variation in predation for the other 3 predators ( $G$ test; all $p>0.1$ ).

After adjustment for incomplete prey ingestion, daily energy intake ( $k J$ predator ${ }^{-1} \mathrm{~d}^{-1}$ ) of Predators $C$ and D was shown to have decreased progressively over the course of each trial (Table 6). Total energy intake over $4 \mathrm{~d}$ was $67.6 \%$ less (mean percentage reduction) than numerical predation and whole prey energy content would suggest (Table 6).

\section{DISCUSSION}

\section{Predation techniques and feeding performance}

In these laboratory experiments, Cancer pagurus did not pursue all decapod prey which were encountered (either by direct physical contact or olfaction), leading
Table 6. Cancer pagurus and Porcellana platycheles prey. Energy intake (based on numbers of prey consumed) over a $4 \mathrm{~d}$ period, without and with adjustment for incomplete prey ingestion. Data are presented in the form of energy intake $(k J)$ predator ${ }^{-1} \mathrm{~d}^{-1}$, derived following procedures described in text and Appendix

\begin{tabular}{|lcrrr|}
\hline $\begin{array}{l}\text { Predator } \\
\text { identity }\end{array}$ & $\begin{array}{c}\text { Energy intake (kJ predator }{ }^{-1} \mathrm{~d}^{-1} \text { ) } \\
\text { Dercentage } \\
\text { trial }\end{array}$ & Unadjusted & $\begin{array}{c}\text { Adjusted } \\
\text { reduction }\end{array}$ \\
\hline \multirow{4}{*}{ C } & 1 & 38.69 & 15.09 & 61.0 \\
& 2 & 19.08 & 8.34 & 56.3 \\
& 3 & 7.42 & 0.14 & 98.1 \\
& 4 & 12.74 & 0.91 & 92.9 \\
& Total & 77.93 & 24.48 & 68.6 \\
D & 1 & 14.33 & 5.41 & 62.3 \\
& 2 & 35.69 & 14.05 & 60.6 \\
& 3 & 17.97 & 6.43 & 64.2 \\
& 4 & 20.60 & 3.74 & 81.9 \\
& Total & 88.59 & 29.63 & 66.6 \\
\hline
\end{tabular}

to recognition success rates less than unity. This result may have been an artifact, reflecting differences in individual predator feeding state at the time of presentation. While noting that juvenile shore crabs Carcinus maenas provide a strong attack stimulus to the portunid crab Liocarcinus puber, ap Rheinallt (1986) documented instances of contacts with specific prey sizes being ignored when mixtures of different-sized $C$. maenas were presented. Therefore, prey abundance may also influence recognition success. For crabs actively foraging in the wild, encounters would most likely occur with single decapod crustacean prey, and recognition success may be expected to approach unity (see also Evans \& Mann 1977).

Pursuit success on decapod crustaceans was high (Fig. 2; Table 2), except for particularly fast moving species (Carcinus maenas, Galathea squamifera). Three pursuit techniques were recognized, more complex behavior than that used to capture epifaunal molluscs, where pursuit is simply the act of picking the prey up in the claws. The grab response was less efficient than pouncing at large relative prey size, most likely due to difficulties in capturing such prey using the pereopods only. Conversely, pouncing was less successful on small prey which were difficult to locate under the abdomen, and consequently escaped (Fig. $2 \mathrm{~B})$. The location of prey, relative to the predator, in these 2 pursuit techniques appeared to be determined principally by mechanoreception. Ap Rheinallt (1986) described similar pursuit behaviors for Liocarcinus puber preying on C. maenas.

Stalking behavior, a distinctive pursuit technique, has not previously been reported for a cancrid crab. Hughes (1966) observed similar behavior for Ocypode ceratophthalmus feeding in the field on sentinel crabs 
Macrophthalmus grandiderii. Prey were perceived by $O$. ceratophthalmus either visually, or by response to movements of prey pereopods in shallow puddles. Due to the low occurrence of stalking behavior in the present study, the specific cues used by Cancer pagurus could not be firmly established. Schembri (1981) described stalking behavior by the leucosid Ebalia tuberosa which adopted a characteristic position in which the claws were stretched forward in front of the body and held parallel to the substrate. Schembri (1981) speculated that because the chelae carry a variety of chemo- and mechano-receptors, E. tuberosa may be comparing sensory inputs from both claws to orientate to a stimulus source. C. pagurus similarly held the claws forward in front of the body during stalking behavior observed in the present study.

Cancer pagurus successfully subdued a wide size range of decapod crustacean prey, although retaliation and autotomy contributed to attack failure with some relatively large prey individuals. Proportional prey size (PROP), expressed as prey carapace length, CL/predator CW was not truly representative of galatheid prey size. At $\mathrm{PROP}=0.3$, the total estimated length (from the tips of the outstretched chelipeds to the posterior end of the flexed abdomen) of a $22 \mathrm{~mm}$ CL Galathea squamifera presented to an $87 \mathrm{~mm} \mathrm{CW} \mathrm{C.} \mathrm{pagurus} \mathrm{was}$ $71 \mathrm{~mm}$.

All decapod prey species reacted to the presence of Cancer pagurus by avoidance behavior and increased locomotory rate. Following capture, differences in defensive capability were apparent. Adult stages of small decapod species (Pilumnus hirtellus, Porcellana platycheles), particularly males, possessed relatively larger chelipeds than juvenile Carcinus maenas and $C$. pagurus of equivalent CW (Fig.1), and were more capable of resisting attack. Differences were also apparent in the frequency of use of autotomy as a defensive measure. Other more subtle behavioral differences may be involved in susceptibility. Weiss (1970) stated that lobsters Homarus americanus preyed less effectively on Cancer borealis than on Cancer irroratus due to the adoption of a closed defensive chela position in the former species and an open lateral merus display in the latter.

Rejection of conspecific prey by Cancer pagurus, observed in this study, provides behavioral verification for the presence of intraspecific avoidance responses in crustaceans, as postulated by Hancock (1974), and Chapman \& Smith (1978) from the results of trapping experiments (see also Richards \& Cobb 1987). These preliminary results, which indicate an influence of feeding history on propensity for intraspecific predation, were further explored in a subsequent series of experiments in which predator diet was more closely controlled (Lawton 1983).

\section{Handling times and prey profitability}

In crustacean:bivalve predatory interaction, breaking time and eating time (sensu Elner \& Hughes 1978) may be readily distinguished. Equivalent handling components in crustacean:crustacean interactions (subjugation and consumption) could not be partitioned accurately. Overall handling time $\left(T_{h}\right)$ was thus the only time component used to examine profitability (see also ap Rheinallt \& Hughes 1985, ap Rheinallt 1986).

For one size-class of Cancer pagurus feeding on Porcellana platycheles prey, profitability increased with RPS (Fig. 2B). Additional handling episodes, observed during preliminary experiments with $P$. platycheles, suggested that this relationship may not hold for all crab sizes (unpubl.). With the additional consideration that a proportion of attacks on large decapod prey may result in the consumption of prey chelipeds only, profitability to be realized from a givensized crustacean prey would clearly be difficult for the predator to assess during the predatory interaction.

Estimation of profitability was further complicated by the fact that prey of large RPS were only partially ingested, perhaps reflecting a limitation in predator foregut capacity and food clearance rate. On examination, the foregut stomachs of Cancer pagurus feeding on large Porcellana platycheles were found to be packed with flesh and exoskeletal material (pers. obs.). For Carcinus maenas ( 8 to $16 \mathrm{~mm}_{\mathrm{l}} \mathrm{CW}$ ) presented to Liocarcinus puber $(70$ to $80 \mathrm{~mm} \mathrm{CW})$, ap Rheinallt (1986) determined mean profitabilities of 3 to $5 \mathrm{~J} \mathrm{~s}^{-1}$ for individual predators at the onset of prey size-selection experiments. These values fall within the range of profitabilities recorded for $P$. platycheles prey offered singly to $C$. pagurus in the present study (Fig. 3b). However, as $C$. maenas prey were consumed by $L$. puber, handling times lengthened, and so profitabilities fell to 1 to $2 \mathrm{~J} \mathrm{~s}^{-1}$ (ap Rheinallt 1986). While L. puber could easily break open $C$. maenas prey, it also did not separate flesh and exoskeleton prior to ingestion, and ap Rheinallt (1986) noted incomplete consumption of large C. maenas prey by $L$. puber.

Hill (1976) suggested that loss of hard prey structures, such as exoskeletal material, was through regurgitation of stomach content on a periodic basis. In the present study, Cancer pagurus was observed to regurgitate finely macerated exoskeletal material up to $30 \mathrm{~h}$ after consuming Porcellana platycheles prey (pers. obs.). Haddon \& Wear (1987), as part of a larger study on feeding biology, monitored regurgitation of shell fragments by the portunid crab Ovalipes catharus after feeding these crabs to satiation on small $(<10 \mathrm{~mm}$ shell length) bivalves Paphies subtriangulata. At $9.5^{\circ} \mathrm{C}$, the average time taken for crabs 49 to $110 \mathrm{~mm} \mathrm{CW}$ to 
regurgitate shell fragments was $16.7 \mathrm{~h}$ (range 14.5 to $21 \mathrm{~h})$. Much shorter times were recorded for a second group of crabs (all $93 \mathrm{~mm} \mathrm{CW}, n=14$ ) feeding on $P$. subtriangulata at $19.5^{\circ} \mathrm{C}$ (average time to regurgitation $=3.75 \mathrm{~h}$; range $=3.17$ to $5.33 \mathrm{~h}$ ). Haddon \& Wear (1987) contrasted their findings with the reference by Hill (1976) to finding small amounts of shell debris in Scylla serrata foreguts after $8.5 \mathrm{~d}$. In other feeding experiments, Haddon \& Wear (1987) observed no regurgitation of exoskeleton fragments when the thalassinid shrimp Callianassa filholi was used as prey, speculating that $O$. catharus was able to break down shrimp exoskeleton in the foregut. The relatively long time to regurgitation observed in the present study may reflect partial breakdown of ingested exoskeletal material. As regurgitation of indigestible material renders the foregut ready for another meal (Haddon \& Wear 1987), this long retention time may be implicated in the progressive reduction in prey consumption on an unrestricted diet of $P$. platycheles (Table 6).

Incomplete prey ingestion has not been taken into account in some estimates of the dietary contribution of crustacean prey. Wolcott (1978) noted that $87 \%$ of the diet of Ocypode quadrata was comprised of the mole crab, Emerita talpoidea (46\%), and the bivalve Donax variablis $(41 \%)$. Based on whole prey energy content, E. talpoidea was estimated to contribute $62 \%$ of the energy intake whilst $D$. variablis represented only $22 \%$. Hill (1979) carried out a similar analysis for the portunid crab Scylla serrata, showing that the crab Ceratophthalmus algoense contributed a disproportionate amount to the energy budget than would be expected from its frequency of occurrence in stomach contents. A similar conclusion was reached by Evans \& Mann (1977) in their analysis of laboratory experiments on predation by the lobster Homarus americanus on Carcinus maenas and the sea urchin Strongylocentrotus droebachiensis. In each of these studies, comparisons were based on the relative calorific content, and body masses of intact prey available to the predators. While the present results substantiate that crustaceans are energetically valuable prey, they cast doubt upon the validity of ranking prey species according to whole prey energy content, and frequency of occurrence in stomach contents.

\section{Foraging tactics}

When presented with an unrestricted diet of Porcellana platycheles, Cancer pagurus recently collected from the field conducted most of their feeding activities from within shelter, exhibiting low predatory responses to prey encountered during activity periods outside shelter. These observations confirm that C. pagurus can successfully ambush mobile epifaunal prey. Consideration of feeding behavior and activity pattern provide an indication of situations in which C. pagurus may use ambushing from its repertoire of foraging techniques. Prey were ambushed both before and after apparently tidally-synchronized activity periods. Such rhythmic activity may correspond to foraging periods in the wild when C. pagurus acts as a 'searcher' (sensu Hughes 1980), moving over a range of subtidal habitats, feeding on sedentary (mussels) or slow-moving prey (gastropods). Before such periods, and upon reoccupation of shelter at the end of a tidal cycle, $C$ pagurus may capture prey which are within its shelter, or which pass close enough to be ambushed. Using similar reasoning, Morales \& Antezana (1983) concluded that porcellanid crabs were a more accessible prey item than gastropods or mussels to the relatively sedentary Chilean stone crab Homalaspis plana. Documentation of ambush predation in natural habitats is obviously required to confirm these laboratory observations: such evidence could be obtained by filming a particular shelter system, known to be frequented by $C$. pagurus, over a number of tidal cycles.

In a subsequent laboratory study (Lawton 1987), diel activity and foraging behavior of juvenile lobsters Homarus americanus was investigated using timelapse video recording and behavioral time-budget analysis. Mussels Mytilus edulis, provided as prey, were picked up, apparently nonselectively, when lobsters ventured out from shelter, and were immediately taken back to shelter for consumption. Lawton (1987) suggested that this shelter-related foraging behavior may minimize risk to juvenile lobsters from fish predation. This consideration may apply to Cancer pagurus which is a common prey of local predatory fish, such as the bass Dicentrachus labrax (Sant 1978).

Inclusion of shelter availability as a feature of laboratory predation experiments using Cancer pagurus (present study), and Homarus americanus (Lawton 1987), yielded novel insight into decapod crustacean foraging behavior. While it remains crucial to obtain field verification of these behavior patterns, there is considerable scope for further laboratory work in settings which recreate structural elements found in natural habitats.

\section{APPENDIX}

\section{Profitability of Porcellana platycheles prey}

Twenty-eight prey $(5.8$ to $13.4 \mathrm{~mm} \mathrm{CW})$, collected from the Treborth site, were killed by immersion in freshwater near boiling point, a procedure which induced autotomy. Weight determinations were made separately for the 2 chelipeds (ch2), and for the body and pereopods $(\mathrm{bp})$ of each prey. Samples were dried at 
$60^{\circ} \mathrm{C}$ for $48 \mathrm{~h}$ to give dry weight (DW), and at $600^{\circ} \mathrm{C}$ for $2 \mathrm{~h}$ to obtain ash-free dry weight (AFDW). This was a biased estimate of AFDW due to endothermic reactions during ashing (Klein-Breteler 1975), thus AFDW values were weighted to derive ash-free carbonate corrected dry weight (AFCC) of various prey body parts. (1) Whole animal $\left(\mathrm{AFCC}_{\mathrm{w}}=\mathrm{AFCC}_{\mathrm{ch} 2}+\mathrm{AFCC}_{\mathrm{bp}}\right.$ ). (2) Body with pereopods $\left(\mathrm{AFCC}_{\mathrm{bp}}\right)$. (3) One cheliped $\left(\mathrm{AFCC}_{\mathrm{ch} 1}=\right.$ $\mathrm{AFCC}_{\mathrm{ch} 2} / 2$ ). $\mathrm{AFCC}$ values were related to prey $\mathrm{CW}$ to determine tissue weight available for consumption (Table 3A).

To adjust for incomplete consumption of large prey (RPS >0.4), 5 predators ( 77 to $87 \mathrm{~mm} \mathrm{CW}$ ) were presented with whole prey, and with single chelipeds from prey of known CW. Four records of the AFCC of remains $\left(\mathrm{AFCC}_{\mathrm{r}}\right)$ were obtained at the following RPS values $( \pm 0.02$ ): $0.4,0.5,0.6,0.7,0.8$ (whole prey); $0.4,0.5,0.6$ 0.7 (chelipeds). Mean values of the proportion of remains, $P_{\text {rem, }}\left(\mathrm{AFCC}_{\mathrm{r}} / \mathrm{AFCC}_{\mathrm{w}}\right.$ or $\left.\mathrm{AFCC}_{\mathrm{r}} / \mathrm{AFCC}_{\mathrm{ch} 1}\right)$ were then related to RPS to yield appropriate correction factors (Table 3B).

Energy content, E, of ingested prey body tissue was derived using a conversion factor, applicable to decapod crustaceans, of $22.195 \mathrm{~kJ} \mathrm{~g}^{-1}$ (AFCC basis; Cummins \& Wuycheck 1971).

Acknowledgements. This work was conducted while I was in receipt of a University of Wales postgraduate research scholarship, for which I am grateful. I thank Dr R. N. Hughes for help and guidance during that stage of my career F. Juanes, S. S. Fouke, and an anonymous reviewer provided substantive comments on earlier drafts of the manuscript.

\section{LITERATURE CITED}

ap Rheinallt, T (1986). Size selection by the crab Liocarcinus puber feeding on mussels Mytilus edulis and on shore crabs Carcinus maenas: the importance of mechanical factors. Mar Ecol. Prog. Ser. 29: 45-53

ap Rheinallt, T., Hughes, R. N. (1985). Handling methods used by the velvet swimming crab Liocarcinus puber when feeding on molluscs and shore crabs. Mar. Ecol. Prog. Ser 25: $63-70$

Butler, $\mathrm{T}$ H. (1954). Food of the commercial crab in the Queen Charlotte Islands Region, Canada. Fish. Res. Bd Can., Prog. Rep. Pac. Coast Stn 99: 3-5

Chapman, C. J., Smith, G. L. (1978). Creel catches of crab, Cancer pagurus L., using different baits. J. Cons. int. Explor. Mer 38: 226-229

Cummins, K. W., Wuycheck, J. C. (1971). Caloric equivalents for investigations in ecological energetics. Mitt. int. Verein theor angew. Limnol. 18: 1-158

Elner, R. W., Beninger, P. G., Linkletter, L. E., Lanteigne, S (1985). Guide to indicator fragments of principal prey taxa in the stomachs of two common Atlantic crab species: Cancer borealis Stimpson, 1859 and Cancer irroratus Say, 1817 Can. Tech. Rep. Fish. Aqquat. Sci. 1403: iv + 20p

Elner, R. W. Campbell, A. (1987). Natural diets of lobster Homarus americanus from barren ground and macroalgal habitats off south-western Nova Scotia, Canada. Mar. Ecol. Prog. Ser. 37: 131-140

Elner, R. W., Hughes, R. N. (1978). Energy maximization in the diet of the shore crab. Carcinus maenas. J. Anim. Ecol. 47: 103-116

Evans, P. D., Mann, K. H. (1977). Selection of prey by American lobsters (Homarus americanus) when offered a choice between sea urchins and crabs. J. Fish. Res. Bd Can. 34: 2203-2207

Gotshall, D. W. (1977). Stomach contents of Northern California Dungeness crabs (Cancer magister). Calif. Fish Game 63: 43-51

Haddon, M., Wear, R. G. (1987). Biology of feeding in the New Zealand paddle crab Ovalipes catharus (Crustacea, Portunidae). N. Z. Jl mar. Freshwat. Res. 21. 55-64

Hancock, D. A. (1974). Attraction and avoidance in marine invertebrates - their possible role in developing an artificial bait. J. Cons int. Explor. Mer 35: 328-331

Hill, B. J. (1976). Natural food, toregut clearance-rate and activity of the crab Scylla serrata. Mar. Biol. 34: 109-116

Hill, B. J. (1979). Aspects of the feeding strategy of the predatory crab Scylla serrata. Mar. Biol. 55: 209-214.

Hirtle, R. W. M., Mann, K. H. (1978). Distance, chemoreception. and vision in the selection of prey by American lobster (Homarus americanus). J. Fish. Res. Bd Can. 35: 1006-1008

Holling, C. S. (1966). The functional response of invertebrate predators to prey density. Mem. ent. Soc. Can. 48: 1-86

Hughes, D. A. (1966). Behavioural and ecological investigations of the crab Ocypode ceratophthalmus (Crustacea: Ocypodidae). J. Zool., Lond. 150: 129-143

Hughes, R. N. (1980). Optimal foraging theory in the marine context. Oceanogr. mar. Biol. A. Rev. 18: 423-481

Ingle, R. W. (1980). British crabs. British Museum (Natural History), Oxford University Press, London

Klein-Breteler, W. C. M. (1975). Food consumption, growth, and energy metabolism of juvenile shore crabs, Carcinus maenas. Neth. J. Sea Res. 9: 255-272

Lau, C. J. (1987). Feeding behavior of the Hawaiian slipper lobster, Scyllarides squammosus, with a review of decapod crustacean feeding tactics on molluscan prey. Bull. mar. Sci. 41. 378-391

Lawton, P. (1983). The feeding biology of the edible crab, Cancer pagurus L. Ph. D. thesis, Univ, of Wales, Bangor

Lawton, P. (1987). Diel activity and foraging behaviour of juvenile American lobsters, Homarus americanus. Can. J. Fish. Aquat. Sci. 44: 1195-1205

Lawton, P., Hughes, R. N. (1985). Foraging behavior of the crab Cancer pagurus feeding on the gastropods Nucella lapillus and Littorina littorea: comparisons with optimal foraging theory. Mar Ecol. Prog. Ser. 27: 143-154

Morales, C. Antezana, T (1983). Diet selection of the Chilean stone crab Homalaspis plana. Mar. Biol. 77: 79-83

Paul, R. K. G. (1981). Natural diet, feeding, and predatory activity of the crabs Callinectes arcuatus and $C$. toxotes (Decapoda, Brachyura, Portunidae). Mar. Ecol. Prog. Ser. 6: 91-99

Pearson, W H., Sugarman, P. C., Woodruff, D. L., Olla, B. L. (1979). Thresholds for detection and feeding behaviour in the Dungeness crab, Cancer magister (Dana). J. exp. mar. Biol. Ecol. 39: 65-78

Richards, R. A., Cobb, J. S. (1987). Use of avoidance responses to keep spider crabs out of traps for American lobsters. Trans. Am. Fish. Soc. 116: 282-285

Sant, F. I. (1978). The bass (Dicentrarchus labrax) in Cardigan Bay. Nature in Wales 16: 123-126

Schembri, P. J. (1981). Feeding in Ebalia tuberosa (Pennant) (Crustacea: Decapoda: Leucosiidae). J. exp. mar. Biol. Ecol. 55: 1-10 
Shelton, R. G. J., Kinnear, J. A. M., Livingstone, K. (1979). A preliminary account of the feeding habits of the edible crab, Cancer pagurus L. off N. W. Scotland. Int. Counc. Explor. Sea Comm. Meet. (Shellfish and Benthos Comm.) $\mathrm{K}: 35: 1-6$

Stevens, B. G., Armstrong, D. A., Cusimano, R. (1982). Feeding habits of the Dungeness crab Cancer magister as determined by the index of relative importance. Mar Biol. 72: $135-145$

Warner, G. F. (1977). The biology of crabs. Elek Science, London

This article was submitted to the editor
Weiss, H. M. (1970). The diet and feeding behavior of the lobster, Homarus americanus, in Long Island Sound. Ph. D. thesis, Univ. of Connecticut, Storrs

Williams, M. J. (1982). Natural food and feeding in the commercial sand crab Portunus pelagicus Linnaeus 1766 (Crustacea: Decapoda: Portunidae) in Moreton Bay, Queensland. J. exp. mar Biol. Ecol. 59: 165-176

Wolcott, T G. (1978). Ecological role of ghost crabs, Ocypode quadrata (Fabricus), on an ocean beach: scavengers or predators? J. exp. mar Biol. Ecol. 31: 67-83

Manuscript received: June 28, 1988

Revised version accepted: November 2, 1988 